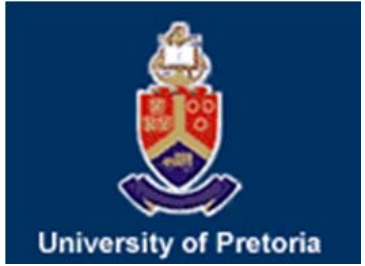

University of Pretoria Department of Economics Working Paper Series

Social Rate of Return to R\&D on Various Energy Technologies: Where Should We Invest More? A Study of G7 Countries

Roula Inglesi-Lotz

University of Pretoria

Working Paper: 2015-49

June 2015

Department of Economics

University of Pretoria

0002, Pretoria

South Africa

Tel: +27 124202413 


\title{
Social Rate of Return to R\&D on Various Energy Technologies: Where Should We Invest More? A Study of G7 Countries.
}

\author{
Roula Inglesi-Lotz \\ Department of Economics, University of Pretoria \\ Pretoria, South Africa
}

\begin{abstract}
The severity of investment in Research and Development (R\&D) in the energy sector is undisputable especially considering the benefits of new technologies to sustainability, security and environmental protection. However, the nature and potential of various energy technologies that are capable to improve the energy and environmental conditions globally is a challenging task for governments and policy makers that have to make decisions on the allocation of funds in $\mathrm{R} \& \mathrm{D}$. To do so, the optimal resource allocation to $R \& D$ should be determined by estimating the social rate of return for $R \& D$ investments. This paper aims to estimate the social rate of return of R\&D on various energy applications and technologies such as energy efficiency, fossil fuels, renewable energy sources, and nuclear for the G7 countries. The results show that primarily R\&D investment on Energy Efficiency technologies and Nuclear are the ones that yield high social benefits for all G7 countries while exactly the opposite holds for Fossil fuels.
\end{abstract}




\section{Introduction}

The severity of investment in Research and Development (R\&D) in the energy sector is indisputable especially considering the benefits of new technologies to sustainability, security and environmental protection. Wong, Chang and Chia (2013) have shown that fossil fuel R\&D drives economic growth in the OECD countries more than actually the fossil fuels consumption does. However, the nature and potential of various energy technologies that are capable to improve the energy and environmental conditions globally is a challenging task for governments and policy makers that have to make decisions on the allocation of funds in R\&D. To do so, the optimal resource allocation to $R \& D$ should be determined by estimating the social rate of return for R\&D investments.

Theoretical and empirical literature has illustrated the central role of $R \& D$ as a significant contributor to growth and development. Primarily empirical studies have estimated the rate of return to $R \& D$ in regressions of productivity growth on measures of $R \& D$ such as $R \& D$ intensity (Grilliches, 1994; Jones and Williams, 1998; Corderi and Cynthia Lin, 2011). Although, different studies accounted for various spillovers consensus has been reached that the social rate of return of $R \& D$ is positive, differs in size among countries and remains significantly above private rates. Tirole (2001) explain why the private rate of return diverge from the socially optimal rate of R\&D: firstly the private sector might under-invest in $R \& D$ because there are positive spillovers included and secondly, when perfect price discrimination does not exist the social surplus from innovation is higher than the private one.

In the international context of climate change, fossil fuel dependence, high energy prices and lack of energy sustainability, there are good reasons to draw attention to the returns of R\&D on energy technologies and innovations. Bointner (2014) argues that between the two major sources 
of learning, namely learning by doing and learning by researching (Garrone and Grilli, 2010), the energy R\&D is subject to the latter. He then continues in explaining the "four grand patterns of energy technological change” as discussed in Grubler et al. (2012): “...namely (a) clustering of related technologies and technology spillovers prevail over stand-alone technologies; (b) the ability to perform a novel energy service is more important than the cost of a new, immature technology; (c) energy supply follows demand, which is given by the available end-use applications; and (d) a low rate of technology diffusion" (Bointener, 2014). However, Sterlacchini (2012) stressed a staggering decline of energy R\&D during the last two decades, due to reforms and restructuring of electricity markets.

It should be noted here that studies focusing on funding directed on energy $R \& D$ activities are rare and focusing primarily on developed economies. The reason for that is not only data availability but also, almost $85-90 \%$ of world's energy R\&D is conducted in the world's richest nations (Breyer et al. 2010) Recently, Coderi and Cynthia Lin (2011) estimated the social rate of return to $R \& D$ in the energy manufacturing industry for a group of OECD countries. They quantified the impact of lagged R\&D on total factor productivity (TFP) using a panel of data. Their results show that $R \& D$ had a positive and significant rate of return with a different magnitude for the various countries.

However, the R\&D spending on energy is broad. The International Energy Agency (IEA) has classified the energy R\&D in seven categories according to the technologies and innovations. Table 1 presents the share of these groups in each of the country's total R\&D expenditures on energy. It can then be seen that the great majority of the energy R\&D in all countries is spent on the nuclear sector, while the cross-country variation of the rest of the energy $R \& D$ groups is high. 
Table 1: Share of the different R\&D Categories to total Energy R\&D (\%)

\begin{tabular}{|c|c|c|c|c|c|c|c|}
\hline Categories & Canada & France & Germany & Italy & Japan & UK & US \\
\hline $\begin{array}{c}\text { Group } 1 \\
\text { Energy Efficiency }\end{array}$ & 14.976 & 6.318 & 6.715 & 14.660 & 7.814 & 10.165 & 15.399 \\
\hline $\begin{array}{c}\text { Group } 2 \\
\text { Fossil fuels }\end{array}$ & 29.858 & 10.675 & 7.742 & 2.985 & 9.543 & 10.442 & 15.292 \\
\hline $\begin{array}{c}\text { Group } 3 \\
\text { Renewable } \\
\text { energies }\end{array}$ & 8.185 & 4.400 & 23.834 & 12.312 & 4.855 & 20.149 & 10.512 \\
\hline $\begin{array}{l}\text { Group } 4 \\
\text { Nuclear }\end{array}$ & 35.316 & 75.184 & 48.719 & 39.429 & 71.559 & 43.008 & 23.026 \\
\hline $\begin{array}{c}\text { Group } 5 \\
\text { Hydrogen and } \\
\text { fuel cells }\end{array}$ & 7.038 & 4.661 & 5.155 & 3.290 & 4.905 & 5.092 & 6.322 \\
\hline $\begin{array}{c}\text { Group } 6 \\
\text { Other power and } \\
\text { storage } \\
\text { technologies }\end{array}$ & 4.252 & 0.562 & 3.736 & 13.938 & 2.841 & 3.838 & 4.073 \\
\hline $\begin{array}{c}\text { Group } 7 \\
\text { Other cross } \\
\text { cutting } \\
\text { technologies }\end{array}$ & 5.151 & 1.032 & 7.597 & 15.622 & 1.935 & 10.760 & 29.665 \\
\hline $\begin{array}{l}\text { Statistical } \\
\text { differences }\end{array}$ & -4.776 & -2.830 & -3.498 & -2.237 & -3.452 & -3.456 & -4.290 \\
\hline Total & 100 & 100 & 100 & 100 & 100 & 100 & 100 \\
\hline
\end{tabular}

Source: International Energy Agency (IEA, 2014). 
This paper aims to estimate the social rate of return of R\&D on various energy applications and technologies such as energy efficiency, fossil fuels, renewable energy sources, and nuclear for the G7 countries (Canada, France, Germany, Italy, Japan, United Kingdom, United States) by using panel data estimations (primarily fixed effects). As used mostly in the literature, we will quantify the impact of lagged R\&D intensity to TFP of the countries. Energy R\&D Data will be derived from the IEA databases while economic data will be provided primarily by the OECD STAN database. All in all, this paper's purpose is to identify which of these energy technologies yield a higher social rate of return of R\&D (if any) and make important policy recommendations.

\section{Methods and data}

A Cobb-Douglas production function is adopted in this analysis of the form:

$Y_{t}=e^{\mu t} Z_{t-1}^{\gamma} K_{t}^{\alpha} L_{t}^{1-\alpha}$

$Z_{t}=R_{t}$

Where $\mathrm{Y}$ is the output produced, $\mathrm{Z}$ is the $\mathrm{R} \& \mathrm{D}$ expenses, $\mathrm{K}$ is the capital, $\mathrm{L}$ is the labor and $\mathrm{R}$ is the expenditures in R\&D. Equation (2) shows no depreciation of stock.

In a growth accounting exercise, we derive the relationship between TFP and R\&D:

$T F P_{t}=\frac{Y_{t}}{K_{t}^{\alpha} L_{t}^{1-\alpha}}$

Equation (3) can finally be transformed in:

$\Delta \ln \left(T F P_{t}\right)=\mu+\tilde{r} \frac{R_{t-1}}{Y_{t-1}}+\varepsilon_{t}$

Where $\tilde{r}=\left(\frac{d Y}{d Z}\right)$ is the rate of return to R\&D. As can be shown in equation (4), TFP is regressed on the R\&D share of output lagged by one period. As Jones and Williams (1998) mention, if the coefficient $r$ is measured at the industry level, it represents the social rate of return. 
The data used are derived primarily from the International Energy Agency (IEA) database "Energy Technology RD\&D budgets", the OECD STAN database and the World Development Indicators of the World Bank for the G7 countries during the period from 1985 to 2012. The group of countries was selected because according to Coderi and Lin (2011) these countries conduct on average $88 \%$ of the energy R\&D in the OECD countries.

Table 2 shows the gross domestic product (GDP) and R\&D expenditures in the seven countries as well as their relative size to the group in percentages. In both indicators, it can be seen that US has the highest share in the sample while Japan follows suit in the group.

Table 2: Descriptive statistics

\begin{tabular}{|l|l|l|l|l|}
\hline & $\begin{array}{l}\text { US dollars millions, } \\
\text { PPP, Constant prices } \\
2005\end{array}$ & $\%$ & $\begin{array}{l}\text { US dollars millions, } \\
\text { PPP, Constant prices } \\
2005\end{array}$ & \% \\
\hline & $\begin{array}{l}\text { Size in terms of total } \\
\text { R\&D in energy }\end{array}$ & $\begin{array}{l}\text { Relative size to the } \\
\text { group }\end{array}$ & Size in terms of GDP & Relative size \\
\hline Canada & 520.024 & 4.844 & 982145.345 & 4.329 \\
\hline France & 976.124 & 9.093 & 1687321.462 & 7.437 \\
\hline Germany & 660.136 & 6.150 & 2454303.972 & 10.818 \\
\hline Italy & 732.646 & 6.825 & 1547616.286 & 6.822 \\
\hline Japan & 3470.010 & 32.326 & 3538803.193 & 15.598 \\
\hline UK & 311.286 & 2.900 & 1757612.186 & 7.747 \\
\hline US & 4064.117 & 37.861 & 10719327.596 & 47.248 \\
\hline & & & & \\
\hline Total & 10734.342 & 100.000 & 22687130.041 & 100.000 \\
\hline
\end{tabular}




\section{Empirical results}

The model specification has a regression equation of the form:

$\Delta \ln \left(\right.$ TFP $\left.P_{i t}\right)=\mu_{i}+\tilde{r}_{i}(\text { RDint })_{i t-1}+\beta$ Period $_{t}+\varepsilon_{i t}$

Where TFP is the total factor productivity for each of the countries $\mathrm{i}$ in each growth rate (differenced natural logs); RDint is the R\&D intensity (lagged 1 period) defined as the ratio of $R \& D$ expenditures to value added in each country; $\mu$ is the country fixed effects and $\varepsilon i t$ is the error term which is assumed to be heteroskedastic (by country) and serially uncorrelated. The parameter $\tilde{r}_{i}$ is the one to be of interest here since it is denoting the country-specific social rate of return of each of the groups of energy R\&D. Following Coderi and Lin (2011), "we used fixed effects rather than random effects panel estimation model since we believe that time -invariant country-level unobservables are potentially correlated with some of the regressors" (Coderi and Lin, 2011: 2782).

The dependent variable as seen in equation (5) is growth in total factor productivity and the regressor is the lagged $R \& D$ intensity. The White's robust error variance estimation procedure is used accounting for the possibility of heteroskedastic errors. Table 3 presents the social rate of return to the various groups of energy $R \& D^{1}$.

\footnotetext{
${ }^{1}$ Appendix A presents the coefficient estimates with their t-statistics.
} 
Table 3: Social rate of return estimates by country (percent)

\begin{tabular}{|l|l|l|l|l|l|l|l|}
\hline & RD1 & RD2 & RD3 & RD4 & RD5 & RD6 & RD7 \\
\hline Canada & 1.423 & -0.635 & -2.082 & 3.640 & -25.259 & -1.590 & -0.777 \\
\hline France & 1.122 & -0.558 & -0.271 & 4.861 & 2.216 & 1.035 & 1.136 \\
\hline Germany & 1.125 & -0.294 & -7.780 & 3.571 & 65.884 & -0.726 & 0.689 \\
\hline Italy & 1.183 & -0.204 & -9.257 & 3.341 & -2.560 & -3.971 & 0.473 \\
\hline Japan & 1.236 & -0.693 & 1.480 & 5.603 & 10.685 & 1.775 & 0.405 \\
\hline UK & 0.931 & -0.487 & 1.299 & 2.611 & -0.185 & 2.666 & -0.588 \\
\hline US & 1.234 & -0.635 & 0.591 & 2.897 & -3.837 & 0.723 & -0.102 \\
\hline
\end{tabular}

Note: in grey, the cells show estimates that were statistically significant

The first interesting fact that can be observed is that the coefficients for Groups 1 (Energy efficiency) and 4 (Nuclear) are all positive and statistically significant. In a sense, the results for Group 4 were expected as the majority of spending occur in that group. The results for Group 1 are showing how important is for the economics that betterment of the use of energy overall. Secondly, it is crucial to note that none of the coefficients for Group 2 (Fossil fuels) is either positive or statistically significant denoting that the society as a whole do not benefit by the investment in technologies for fossil fuels usage. The rest of the groups show a variety of results depending on the country. It is interesting to see that although US invests most than the other countries, it does not receive the same social return from the investment shows a statistically insignificant coefficient only for Groups 2 and 3 (Fossil fuels and Renewable energies). 


\section{Conclusions}

In this paper we have estimated the social rate of return of $R \& D$ on various energy applications and technologies such as energy efficiency, fossil fuels, renewable energy sources, and nuclear for the G7 countries (Canada, France, Germany, Italy, Japan, United Kingdom, United States) by using panel data estimations (primarily fixed effects). Following the literature, the impact of lagged R\&D intensity to TFP of the countries was quantified to do so. All in all, this paper's purpose was to estimate a lower limit for the social rate of return by using a narrow definition of spillover effects.

Following the approach used by Coderi and Lin (2011), our results yield a lower bound estimate of the social rate of return due to the assumptions and limitations of our approach. The primary focus is on contemporaneous within-country $R \& D$ spillovers, we do not account for $R \& D$ spillovers between industries, intertemporal or inter-country spillovers. Also, the way of measuring productivity here does not adjust for improvements in human capital.

The results show that primarily R\&D investment on Energy Efficiency technologies and Nuclear energy are the ones that yield high social benefits for all G7 countries while exactly the opposite holds for Fossil fuels. There several policy implications of these results. The results show the variety of social benefits gained by various groups in various countries showing that not one policy fits all. Policy makers can count on promoting R\&D in the fields of energy efficiency and nuclear in giving them high social returns. They should hence rethink on distinguishing the investment accordingly. By no means, the results suggest that $R \& D$ investment should be quit for all the other energy technologies apart from those that improve energy efficiency and nuclear production. It might on the contrary be argued that the lack of sufficient and properly directed R\&D investment in other Groups of energy R\&D is the main reason for the absence of social 
returns. One should always keep in mind though that our estimates are lower bound estimates and the need for funding nationally and internationally as well as the need for incentives may be even greater.

\section{Appendix A}

Dependent variable: differenced total factor productivity

\begin{tabular}{|l|l|l|l|l|l|l|l|l|l|l|l|l|l|l|}
\hline & RD1 & & RD2 & RD3 & & RD4 & & RD5 & & RD6 & & RD7 & \\
\hline Canada & 0.014 & $* *$ & -0.006 & -0.021 & & 0.036 & $* *$ & -0.253 & $* * *$ & -0.016 & $* * *$ & -0.008 & \\
\hline & 2.563 & & 0.426 & -1.539 & & 2.601 & & -3.043 & & 0.000 & & 0.186 & \\
\hline France & 0.011 & $* *$ & -0.006 & -0.003 & & 0.049 & $* *$ & 0.022 & & 0.010 & & 0.011 & \\
\hline & 2.193 & & 0.463 & -0.413 & & 2.436 & & 0.275 & & 0.327 & & 0.667 & \\
\hline Germany & 0.011 & $* *$ & -0.003 & -0.078 & $* * *$ & 0.036 & $* *$ & 0.659 & $* * *$ & -0.007 & & 0.007 & \\
\hline & 2.243 & & 0.647 & -3.639 & & 2.307 & & 4.736 & & 0.115 & & 0.108 & \\
\hline Italy & 0.012 & $* *$ & -0.002 & -0.093 & $* * *$ & 0.033 & $* *$ & -0.026 & & -0.040 & $* * *$ & 0.005 & \\
\hline & 2.374 & & 0.726 & -5.337 & & 2.604 & & -1.514 & & 0.000 & & 0.223 & \\
\hline Japan & 0.012 & $* *$ & -0.007 & 0.015 & & 0.056 & $* *$ & 0.107 & $* * *$ & 0.018 & $* *$ & 0.004 & $* *$ \\
\hline & 2.036 & & 0.387 & 0.825 & & 2.300 & & 4.090 & & 0.011 & & 0.042 & \\
\hline UK & 0.009 & $* *$ & -0.005 & 0.013 & $* * *$ & 0.026 & $* *$ & -0.002 & & 0.027 & & -0.006 & \\
\hline & 2.267 & & 0.323 & 2.833 & & 2.411 & & -0.170 & & 0.112 & & 0.474 & \\
\hline US & 0.012 & $*$ & -0.006 & 0.006 & & 0.029 & $* *$ & -0.038 & & 0.007 & & -0.001 & \\
\hline & 1.915 & & 0.409 & 0.828 & & 2.380 & & -0.681 & & 0.644 & & 0.764 & \\
\hline R-squared & 0.985 & & 0.987 & & & & 0.986 & & 0.993 & & 0.986 & & 0.985 & \\
\hline Observations & 144 & & 139 & & & & 149 & & 50 & & 138 & & 132 \\
\hline
\end{tabular}

Note: $\left.{ }^{* * *}\right)[* * *]$ denote $10 \%, 5 \%$ and $1 \%$ level of significance; the figures in italics are the $t-$ statistics 


\section{References}

Bointner, R. (2014). Innovation in the energy sector: Lessons learnt from R\&D expenditures and patents in selected IEA countries. Energy Policy, 73: 733-747.

Coderi, D., Cynthia Lin, C.-Y. (2011). Measuring the social rate of return to R\&D in coal, petroleum and nuclear manufacturing: A study of OECD countries. Energy Policy, 39: 27802785.

Garrone, P., Grilli, L. (2010). Is there a relationship between public expenditures in energy R\&D and carbon emissions per GDP? An empirical investigation. Energy Policy, 38: 5600-5613.

Grilliches, Z. (1994). Productivity, R\&D and the data constraint. American Economic Review, 84 (1): $1-23$.

Grubler, A., Aguayo, F., Gallagher, K., Hekkert, M., Jiang, K. Mytelka, L., Neij, L., Nemet, G., Wilson, C. (2012). Chapter 24- policies for the energy technology innovation system (ETIS), Global Energy Assessment (GEA) - Toward a Sustainable Future. Cambridge University Press, Cambridge, UK and New York, NY, USA, 1665-1744.

International Energy Agency (IEA). (2014). Energy technologies RD\&D Budgets.

Jones, C.I., Williams, J.C. (1998). Measuring the social return to R\&D. The Quarterly Journal of Economics, 113(4): 1119-1135.

Sterlacchini, A. (2012). Energy R\&D in private and state-owned utilities: An analysis of the major world electric companies. Energy Policy, 41: 494-506.

Tirole, J. (2001). The Theory of Industrial Organisation. MIT Press, Cambridge MA.

Wong, S.L., Chang, Y., Chia, W.-M. (2013). Energy Consumption, energy R\&D and real GDP in OECD countries with and without oil reserves. Energy Economics 40: 51-60. 